S. Thatje $\cdot$ J. A. Calcagno $\cdot$ G. A. Lovrich $\cdot$

F. J. Sartoris $\cdot$ K. Anger

\title{
Extended hatching periods in the subantarctic lithodid crabs Lithodes santolla and Paralomis granulosa (Crustacea: Decapoda: Lithodidae)
}

Published online: 13 May 2003

(C) Springer-Verlag and AWI 2003

\begin{abstract}
Temporal pattern of hatching was studied in the subantarctic lithodid crabs Lithodes santolla (Molina) and Paralomis granulosa (Jaquinot) from the Argentine Beagle Channel. In both species, larval hatching occurred in low daily numbers over an extended period of up to several weeks, depending on hatch size. Low daily hatching activity and low oxygen-consumption rates in freshly hatched $P$. granulosa larvae are discussed as life history adaptations to, and/or physiological constraints by, the environmental conditions of high latitudes.
\end{abstract}

Keywords Stone crabs - Hatching mode - Behaviour · Energy investment $\cdot$ Reproduction

\section{Introduction}

Hatching is one of the most conspicuous behavioural phenomena in marine and terrestrial decapods (e.g. Saigusa and Hidaka 1978; Anger et al. 1994). Hatching synchrony is principally assumed to be controlled by the combination of internal rhythms and environmental

Communicated by H.-D. Franke

S. Thatje $(\varangle) \cdot$ F. J. Sartoris

Alfred Wegener Institute for Polar and Marine Research,

PO Box 120 161, 27515 Bremerhaven, Germany

e-mail: sthatje@awi-bremerhaven.de

\section{J. A. Calcagno}

Facultad de Ciencias Exactas y Naturales,

Universidad de Buenos Aires,

Intendente Guiraldes 2160, Cdad Universitaria C1428EHA,

Buenos Aires, Argentina

G. A. Lovrich

Consejo Nacional de Investigaciones Científicas y Técnica,

Centro Austral de Investigaciones Científicas,

CADIC, CC 92, V9410BFD Ushuaia, Tierra del Fuego, Argentina

\section{K. Anger}

Biologische Anstalt Helgoland,

Alfred Wegener Institute for Polar and Marine Research,

Helgoland, Germany conditions (Forward 1987; DeVries and Forward 1989, 1991; Zeng and Naylor 1996, 1997). Primary abiotic signals for hatching behaviour in decapod females are well studied and known to result in, for example, tidal, lunar or diurnal hatching rhythms (DeCoursey 1983; DeVries et al. 1983; Saigusa and Kawagoye 1997; Zeng and Naylor 1997). They have been most intensively studied in coastal and estuarine species (e.g. Anger et al. 1994). The hatching of larvae is based on chemical and behavioural interactions between late embryos and the brooding female (Naylor 1976; Saigusa and Iwasaki 1999; Saigusa and Terajima 2000), although the hierarchical order of factors involved in hatching is not yet well understood. Hatching rhythms related to abiotic and biotic cycles, including primary production, allow for a synchronisation of reproduction with favourable environmental conditions (Starr et al. 1990, 1994). This may aid larval dispersal, growth and survival. However, little is known of hatching modes in decapod species from high latitudes and the deep sea, where some species have developed a food-independent mode of larval development.

We studied the hatching mode in the subantarctic lithodid crabs Lithodes santolla and Paralomis granulosa from the Argentine Beagle Channel. Both species follow a completely lecithotrophic larval development (Calcagno et al., 2003; Lovrich et al. 2003). Our results are discussed in relation to environmental and physiological constraints affecting decapod life histories and survival in cold waters.

\footnotetext{
Methods

Capture and maintenance of ovigerous females

Ovigerous females of Lithodes santolla and Paralomis granulosa were caught at about 15 to $30 \mathrm{~m}$ depth using commercial fishery traps in the Argentine Beagle Channel $\left(54^{\circ} 53.8^{\prime} \mathrm{S}, 68^{\circ} 17.0^{\prime} \mathrm{W}\right)$ in April 2001. The crabs were kept in aquaria at $6 \pm 0.5^{\circ} \mathrm{C}$ in the Centro Austral de Investigaciones Científicas (CADIC) in Ushuaia. In May, the lithodids were transported on board the German scientific research vessel R.V. "Polarstern" to Bremerhaven and finally to the
} 
Table 1 The effect of water temperature on the oxygen consumption of zoea I of Paralomis granulosa

\begin{tabular}{lll}
\hline Temperature $\left({ }^{\circ} \mathrm{C}\right)$ & $\begin{array}{l}\text { Oxygen consumption } \\
\left(\mu \mathrm{g} 0_{2} / \text { h } \times \text { individual }\right)\end{array}$ \\
\cline { 2 - 3 } & Mean & $\mathrm{SD}$ \\
\hline 1 & 1.38 & 0.47 \\
3 & 1.30 & 0.10 \\
6 & 1.59 & 0.55 \\
9 & 1.94 & 0.42 \\
12 & 3.35 & 0.56 \\
15 & 3.98 & 0.96 \\
\hline
\end{tabular}

marine biological laboratory in Helgoland (Germany). During this cruise of about 1 month, water was kept at $6 \pm 0.5^{\circ} \mathrm{C}$ and was changed three times per week. Food (squid) was given twice a week.

In the laboratory, maintenance of females and rearing of larvae took place under constant temperature $\left(6 \pm 0.5^{\circ} \mathrm{C}\right)$ and salinity $(32 \%)$, and a 12:12 h light:dark rhythm. Ovigerous females were kept individually in flow-through tanks of at least 351 .

Newly hatched larvae were collected from the overflow filters (300- $\mu \mathrm{m}$ mesh size). Since almost all larvae hatched at night, sampling and counting of larvae was done every morning.

Hatching of both species was studied during 7 weeks. Some females were still carrying remains of egg-clutches when this study had to be finished for logistic reasons; therefore, we cannot present complete hatching curves for all females studied. The theoretical number of eggs in each egg mass was calculated after the fecundity-CL (carapace length) relationships available from the literature for $P$. granulosa (Lovrich and Vinuesa 1993) and $L$. santolla (Lovrich 1997).

\section{Oxygen consumption measurements}

Freshly hatched larvae of $P$. granulosa taken for measurements of oxygen consumption were reared individually in 100-ml cups with filtered sea water of constant temperature (see Table 1). Oxygen consumption was measured in the middle of the zoea-I moulting cycle. It was measured in a closed system with a 2-ml gas-tight glass syringe used as a respirometer chamber and oxygen microoptodes (Pre Sens, Neuburg a. d. Donau, Germany). The syringe was filled with aerated sea water $(100 \%$ oxygen saturation) and the optode (tip size from $<30$ to $100 \mu \mathrm{m}$ ) was inserted from the side of the cannula. Prior to insertion in the syringe, the optode was calibrated and its drift recorded. Blank measurements in empty syringes revealed no oxygen consumption (due to bacterial contamination) during the measuring period (up to $1 \mathrm{~h}$ ). The larvae were carefully transferred into the syringe with a pipette and subsequently the volume was reduced to $1 \mathrm{ml}$. Mixing of the water inside the syringe was achieved by the movement of the larvae. Variation in the position of the sensitive tip of the optode confirmed that no oxygen gradient occurred inside the chamber. Measurements were terminated when the oxygen saturation decreased below $80 \%$ (15-60 min). Oxygen consumption of larval $P$. granulosa was measured at temperatures ranging from $1^{\circ}$ to $15^{\circ} \mathrm{C}$ $(n=5-8)$, which roughly represents their range of temperature tolerance (Anger et al. 2003). At the end of the measurements, optodes were removed and recalibrated. All measurements and calibrations were carried out in coolers at temperatures corresponding to the incubation temperature.

\section{Results}

Hatching was studied in nine females of Paralomis granulosa and three females of Lithodes santolla over a period of about 7 weeks (Figs. 1, 2). Total amount of hatched larvae per female varied from 426 to 2,915 and from 204 to 3,821 larvae in P. granulosa (Fig. 1) and $L$. santolla (Fig. 2), respectively. The actual numbers, however, are an underestimation, since not all females (except females A, B, E of $P$. granulosa) had finished hatching their larvae when this study was terminated (see Figs. 1, 2). The average daily hatching rates were $52.9 \pm 52.3$ (range 0-379) and 53.4 \pm 88.2 (range 0-366) in $P$. granulosa and $L$. santolla, respectively. In $P$.
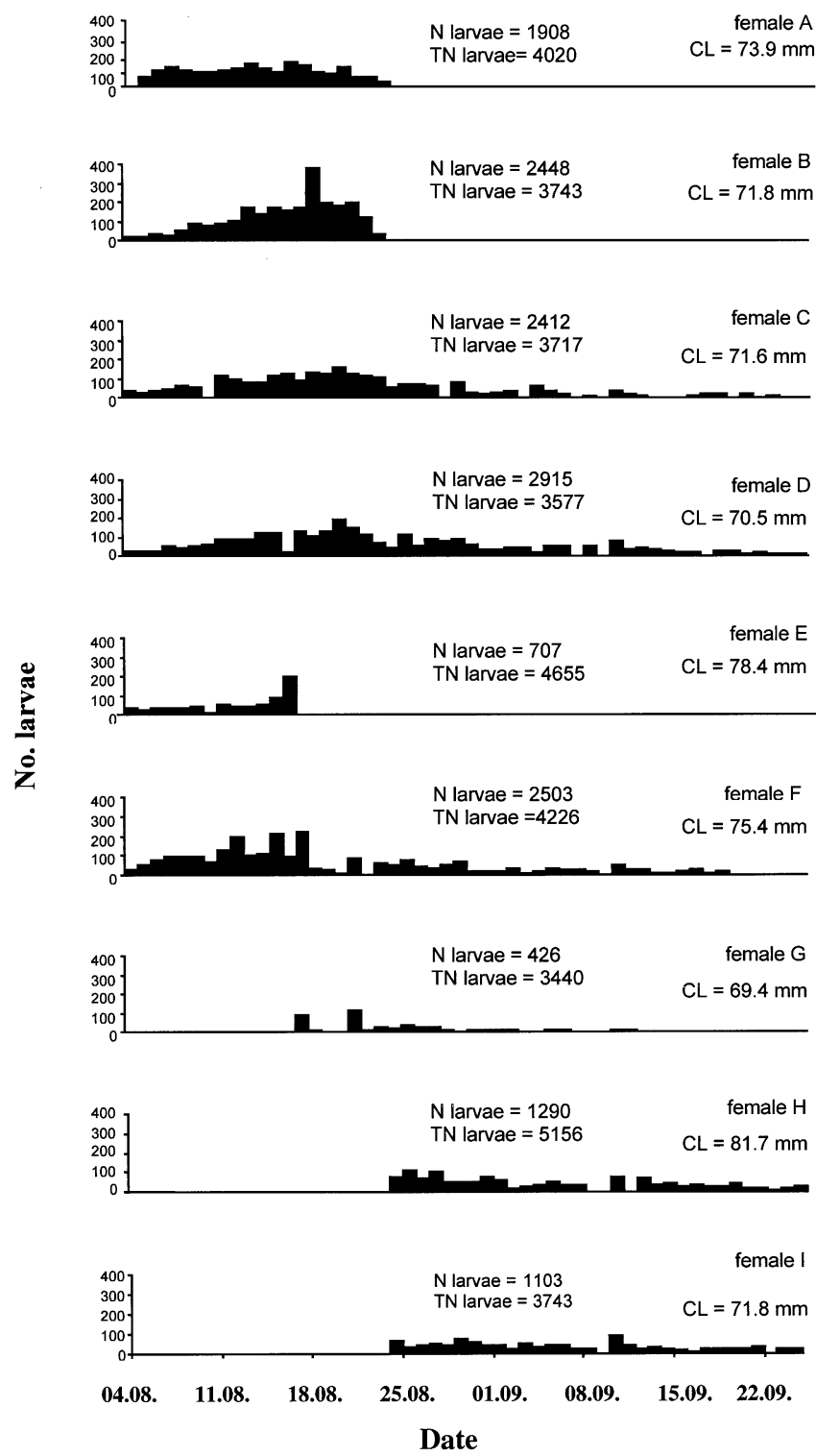

Fig. 1 Daily hatching numbers in Paralomis granulosa (Jaquinot) from the subantarctic Beagle Channel in 2001. Only the females A, $\mathrm{B}$ and $\mathrm{E}$ completed the hatching of all larvae within the study period. TN larvae Theoretical egg/larvae number; $C L$ carapace length 

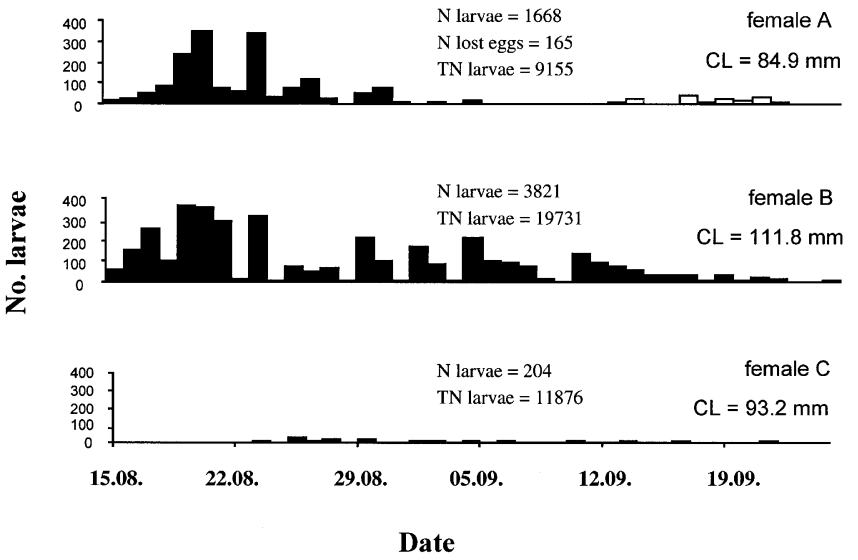

Fig. 2 Daily hatching numbers in Lithodes santolla (Molina) from the subantarctic Beagle Channel in 2001. Open bars the numbers of lost eggs. TN larvae Theoretical egg/larvae number; $C L$ carapace length

granulosa and $L$. santolla, the total hatching period lasted between 13 and 61 days and 35 and 41 days, respectively. Again, the maximum values were underestimated, because at the end of the study most females were still carrying remains of their egg masses.

Depending on incubation temperature, the oxygen consumption of the larvae varied between $1.38\left(1^{\circ} \mathrm{C}\right)$ and $3.98\left(15^{\circ} \mathrm{C}\right) \mu \mathrm{gO}_{2} / \mathrm{h} \times$ individual $(r=0.94 ; P=<0.01$; Table 1).

\section{Discussion}

Larval release in decapods is known to occur frequently in response to abiotic environmental conditions, such as lunar or tidal cycles, leading to synchronised hatching which usually does not exceed a period of a few hours to days (DeCoursey 1983; DeVries et al. 1983; Saigusa and Kawagoye 1997; Zeng and Naylor 1997). Although aquatic invertebrate embryos are usually tolerant of low oxygen concentrations, egg masses are size-limited, owing to oxygen gradients (Strathmann and Strathmann 1995). Decapods, which produce compact egg masses of up to several centimetres in diameter, compensate oxygen deficiency in the centre of their egg-masses mainly by abdominal flapping. This maternal-care behaviour tends to increase during late embryonic development when the oxygen demand of the embryos increases (Nakanishi 1985; Naylor et al. 1999; Fernández et al. 2000; Baeza and Fernández 2002). The energetic cost of brooding depends mainly on the size of the egg mass and on oxygen partial pressure. Since the oxygen partial pressure in sea water is temperature-dependent, these costs should be higher in temperate and warm shallow subtidal zones than in the deep sea and at high latitudes.

In cold environments, such as the Antarctic and adjacent regions, the hatching mode of decapods is little known. Biogeographic limits in decapod distribution, in particular the absence of reptant crabs in polar areas, have been assumed to be due to low temperatures in combination with food limitation, owing to short primary-production periods, both affecting larval survival (for recent review, see Anger 2001). Recently, these distribution patterns were proposed to be due to physiological constraints at low temperatures; namely, the Reptantia are poor $\mathrm{Mg}^{2+}$ regulators which may suffer narcotising effects induced by low temperatures in combination with high $\mathrm{Mg}^{2+}$ levels in the haemolymph (Frederich et al. 2001). As a consequence, brooding activities such as abdominal flapping should be dramatically reduced at low temperatures.

Limited food availability at high latitudes may be compensated by lecithotrophic larval development, which has been shown in lithodid crabs (Anger 1996; Shirley and Zhou 1997), including the species studied here, $P$. granulosa and L. santolla (Calcagno et al., 2003; Lovrich et al. 2003). Embryonic development in these species is known to last between about 1 and 2 years (L. santolla 9 10 months, Vinuesa 1984; P. granulosa 18-22 months, Lovrich and Vinuesa 1993).

Freshly hatched larvae of $P$. granulosa showed low oxygen-consumption rates at low temperatures in our study (Table 1); the rate, however, increased strongly with increasing temperature. The same tendency has been reported in other lithodid species (Nakanishi 1985; Anger 1996). Low larval oxygen consumption may be a consequence of low-temperature regimes and restricted maternal aid in oxygen supply. Active enhancement of the hatching by means of strong abdominal flapping was not observed in our study. Low daily hatching rates suggest that hatching in lithodids is associated with little activity and low energetic costs for the female. Lecithotrophic development makes larvae independent of food, so that there is no need for hatching to coincide with periods of high primary production in these species. Their larvae show a demersal drifting behaviour and do not occur in the productive upper parts of the water column (for discussion, see Lovrich 1999).

Paralomis granulosa and L. santolla are known to carry up to 10,000 and 32,000 eggs per clutch, respectively (Lovrich 1997). Since the females of $L$. santolla used in this study were on average much smaller than in natural populations (cf Lovrich et al. 1999), hatching in nature may last even longer than 7 weeks. This is indicated also by those females in both species which had not completed hatching at the end of the study period. Differences between total hatching numbers obtained during our study period of about 7 weeks and the estimated theoretical amount of larvae in each clutch support this point of view (see Figs. 1, 2), not taking into account the females A, B, and E of $P$. granulosa which apparently hatched most of their larvae before being individualised (Fig. 1). Since in some females the study included both the beginning and end of larval hatching, we probably have not missed conspicuous peaks in hatching. This is also supported by the fact that daily means in hatching numbers were rather similar. The continuous release of demersal larvae may have an adaptive value, since it enhances the dispersal and may reduce the susceptibility to pelagic predation. 
If we assume that the duration of embryonic development in decapods is not strictly determined genetically, but is also dependent on temperature and dissolvedoxygen level, oxygen gradients in egg masses of brachyuran crabs could be responsible for the delay in hatching of larvae from the innermost layers of the egg mass (Chaffee and Strathmann 1984), thus explaining the occurrence of extended hatching periods.

Acknowledgements We are thankful to Federico Tapella and Alejandro Chizzini for assistance in the field and transportation of crabs from Ushuaia, Argentina, to Punta Arenas, Chile. Sylvia Terbeck, Kirsten Röhr and Uwe Nettelmann kindly assisted in laboratory cultures of lithodids. This project is part of a bilateral cooperation between the Foundation Alfred Wegener Institute for Polar and Marine Research, Bremerhaven, Germany, the Centro Austral de Investigaciones Científicas y Técnica, Ushuaia, Tierra del Fuego, and the Universidad de Buenos Aires, Argentina. We are indebted to the International Bureau of the German Ministry of Research (BMBF, Arg 99/002) and the Argentine Secretaría Nacional para la Tecnología, Ciencia e Inovación Productiva (SETCIP) for continuous financial support of this bilateral cooperation during the last years. Special thanks are due to captain W. Pahl of the German R.V. "Polarstern" for his great help in solving logistical problems during the transport of the crabs from South America to the lab in Germany. Thanks are also due to the crews of the R.V.s "Polarstern" and "Uthörn" for assistance during the long trip home.

\section{References}

Anger K (1996) Physiological and biochemical changes during lecithotrophic larval development and early juvenile growth in the northern stone crab, Lithodes maja (Decapoda: Anomura). Mar Biol 126:283-296

Anger K (2001) The biology of decapod crustacean larvae. In: Vonk R (ed) Crustacean Issue 14. Balkema, Sweets and Zeitlinger, Lisse, pp 1-420

Anger K, Spivak E, Bas C, Ismael D, Luppi T (1994) Hatching rhythms and dispersal of decapod crustacean larvae in a brackish coastal lagoon in Argentina. Helgol Wiss Meeresunters 48:445-466

Anger K, Thatje S, Lovrich GA, Calcagno JA (2003) Larval and early juvenile development of Paralomis granulosa reared at different temperatures: tolerance of cold and food limitation in a lithodid crab from high latitudes. Mar Ecol Prog Ser (in press)

Baeza JA, Fernández M (2002) Active brood care in Cancer setosus (Crustacea: Decapoda): the relationship between female behaviour, embryo oxygen consumption and the cost of brooding. Funct Ecol 16:241-251

Calcagno JA, Thatje S, Anger K, Lovrich GA, Kaffenberger (2003) Changes in biomass and chemical composition during lecithotrophic larval development of the southern stone crab Paralomis granulosa (Jaquinot). Mar Ecol Prog Ser (in press)

Chaffee C, Strathmann RR (1984) Constraints on egg masses. I. Retarded development within thick egg masses. J Exp Mar Biol Ecol 84:73-83

DeCoursey PJ (1983) Biological timing. In: Vernberg FJ, Vernberg WB (eds) The biology of Crustacea 7. Behavior and ecology. Academic Press, New York, pp 107-162

DeVries MC, Forward RB (1989) Rhythms in larval release of the sublittoral crab Neopanope sayi and the supralittoral crab Sesarma cinereum (Decapoda: Brachyura). Mar Biol 100:241248

DeVries MC, Forward RB (1991). Control of egg-hatching time in crabs from different tidal heights. J Crustac Biol 11:29-39

DeVries MC, Epifanio CE, Dittel AI (1983) Lunar rhythms in the egg hatching of the subtidal crustacean: Callinectes arcuatus
Ordway (Decapoda: Brachyura). Estuar Coast Shelf Sci 17:717-724

Fernández M, Bock C, Pörtner HO (2000) The cost of being a caring mother: the ignored factor in the reproduction of marine invertebrates. Ecol Lett 3:487-494

Forward RB (1987) Larval release rhythms of decapod crustaceans: an overview. Bull Mar Sci 41:165-176

Frederich M, Sartoris FJ, Pörtner HO (2001) Distribution patterns of decapod crustaceans in polar areas: a result of magnesium regulation? Polar Biol 24:719-723

Lovrich GA (1997) La pesquería mixta de las centollas Lithodes santolla y Paralomis granulosa (Anomura: Lithodidae) en Tierra del Fuego, Argentina. Invest Mar (Valparaíso) 25:41-57

Lovrich GA (1999) Seasonality of larvae of Brachyura and Anomura (Crustacea, Decapoda) in the Beagle Channel, Argentina. Sci Mar 63 [Suppl 1]:347-354

Lovrich GA, Vinuesa JH (1993) Reproductive biology of the false southern king crab (Paralomis granulosa, Lithodidae) in the Beagle Channel, Argentina. Fish Bull 91:664-675

Lovrich GA, Tapella F, Romero MC (1999) Estado de la pesquería mixta de centollón Paralomis granulosa y de la centolla Lithodes santolla en el Canal Beagle, Argentina. Informe 1998. Contrib Cient CADIC 33:1-25

Lovrich GA, Thatje S, Calcagno JA, Anger K, Kaffenberger A (2003) Changes in biomass and chemical composition during lecithotrophic larval development of the southern king crab Lithodes santolla (Molina). J Exp Mar Biol Ecol 288:65-79

Nakanishi T (1985) The effect of the environment on the survival rate, growth and respiration of eggs, larvae and post-larvae of king crab (Paralithodes camtschatica). Proc Int King Crab Symp, Anchorage Alaska, pp 167-185

Naylor E (1976) Rhythmic behaviour and reproduction in marine animals. In: Newell RR (ed) Adaptation to environment. Butterworth, London, pp 383-429

Naylor JK, Taylor EW, Bennett DB (1999) Oxygen uptake of developing eggs of Cancer pagurus (Crustacea: Decapoda: Cancridae) and consequent behaviour of the ovigerous females. J Mar Biol Assoc UK 79:305-315

Saigusa M, Hidaka T (1978) Semilunar rhythm in the zoea-release activity of the land crabs Sesarma. Oecologia 37:163-176

Saigusa M, Iwasaki H (1999) Ovigerous-hair stripping substance (OHSS) in an estuarine crab: purification, preliminary characterization, and appearance of the activity in the developing embryos. Biol Bull 197:174-187

Saigusa M, Kawagoye O (1997) Circatidal rhythm of an intertidal crab, Hemigrapsus sanguineus: synchrony with unequal tide height and involvement of a light-response mechanism. Mar Biol 129:87-96

Saigusa M, Terajima M (2000) Hatching of an estuarine crab, Sesarma haematocheir: from disappearance of the inner (E3) layer to rupture of the egg case. J Exp Zool 287:510-523

Shirley TC, Zhou S (1997) Lecithotrophic development of the golden king crab Lithodes aequispinus (Anomura: Lithodidae). J Crustac Biol 17:207-216

Starr M, Himmelman JH, Therriault JC (1990) Direct coupling of marine invertebrate spawning with phytoplankton blooms. Science 247:1071-1074

Starr M, Therriault JC, Conan GY, Comeau M, Robichaud G (1994) Larval release in a sub-euphotic zone invertebrate triggered by sinking phytoplankton particles. J Plankton Res 16:1137-1147

Strathmann RR, Strathmann MF (1995) Oxygen supply and limits on aggregation of embryos. J Mar Biol Assoc UK 75:413-428

Vinuesa JH (1984) Sistema reproductor, ciclo y madurez gonadal de la centolla (Lithodes antarcticus) del Canal Beagle. Contr. $\mathrm{N}^{\circ}$ 441, INIDEP, Mar del Plata, Argentina: pp 75-95

Zeng C, Naylor E (1996) Synchronisation of endogenous tidal vertical migration rhythms in laboratory-hatched larvae of the crab Carcinus maenas. J Exp Mar Biol Ecol 198:269-289

Zeng C, Naylor E (1997) Rhythms of larval release in the shore crab Carcinus maenas (Decapoda: Brachyura). J Mar Biol Assoc UK 77:451-461 